\title{
The Use of Community Language Learning Method in Teaching English to Women Painters and Sellers of Bark Painting in Papua-Asei Island
}

\author{
Ruth Naomi Nancy Wompere \\ Lecturer, Faculty of Teacher Training and Education \\ Cenderawasih University, Papua, Indonesia \\ nwompere@gmail.com
}

\begin{abstract}
Informal English teaching for people in creative economy is still lacking or even never done before in Jayapura, Papua. Therefore, this study aimed to conduct teaching English for women painters and sellers of bark painting in Asei Island, East Sentani, Jayapura Regency. This research was a qualitative research. The subjects of this study were 20 women whom other than being a housewife, they also were painters and sellers of bark painting. The data was taken by doing teaching process using the Community Language Learning method. This method was used because the process of language learning occurs within a community, so that learning that happened was expected be more effective. The data showed that the teaching and learning process using Community Language Learning method can be implemented well. There were two main steps in learning that occurred which were reflection and recording. The reflection phase happened when the students reflected on the language as the teacher read the transcript three times. The recording phase happened when the students felt comfortable in producing some sentences to be recorded. The supporting factor of implementing the method in teaching process was the learning can happen due to the community value, and the hindrance factor was the time constraints.
\end{abstract}

Keywords-Bark Painting; Community Language Learning

\section{INTRODUCTION}

Learning English as a foreign language is not limited only on formal education in schools and in college with young participants. Informal educations provide chance for those who want to learn English for developing their knowledge or for specific purposes.

The necessity to learn Language English increases when the learner finds that is beneficial. In working or business world, English as International language is used as the main language for communication among the participants who do not speak English as their first language. Those speakers cover not only those who involve in international global businesses, but also those running local scaled small bussinesses.

The development in local business is in line with the improvement of the community's income. Local business marketing through national and international large-scale events are believed to be able to develop small businesses and to promote them nationally and internationally.

One of famous unique local businesses in the District of Jayapura, Papua, Indonesia is Malo or bark crafting business. Bark crafting practice can be found in the District of Jayapura, specifically on the island of Asei, East Sentani. According to the folklore, only the people of Asei Island have the rights to make this type of craft. In annual event of FDS (Sentani Lake Festival), in the District of Jayapura, bark crafts are presented in various products such as painting, bags, head cover, accessories, and so on. This bark crafting is favored by national and international customers. Thus, it also contributes in tourism.

With FDS in their annual agenda, the women who paint and sell Malo are encouraged to know English in order to be able to communicate with foreigners coming to FDS or even with those coming directly to Asei Island to buy bark craftings.

Specific method to teach English for the women is an important factor to consider since many of them are not young anymore. One of the methods is 'Community Language Learning'. Teaching English. Using CLL method means that the teachers are expected to create supportive learning atmosphere. This means that teachers and student have to work together.They have to appreciate each other. The design has to allow the learners communicate and interact with other fellow learners freely. 


\section{METHODS}

This was a qualitative research. The subject of this research was 20 women who work as painters and sellers of bark painting. The data was taken from observation and interview. The primary data was taken from the observation during the teaching English process. The secondary data was taken from the interview with the subjects in order to find out some factors that supported and hindered the teaching process. The research was conducted in Asei Village, Sentani Timur, Jayapura Regency.

\section{Teaching English Using Community Language Learning Method}

\section{FINDING AND DISCUSSION}

Community Language Learning is a method for teaching English at formal and non-formal level. This method is known as a method for learning languages in a community or in groups.

Based on the observations, teaching English using Community Language Learning method is started with introducing basics introduction oneself, greetings, and then about bargaining. The teaching activities were followed by the participant supportively. Researchers which were also the teachers found good enthusiasm among the participants. The participants could follow any explanation very well, and had active contribution.

This method perceives the participants as "whole humans", in other words as holistic (comprehensive) human being. Since learning must cover some aspects such as cognitive and affective elements, then the teachings were done with some background adjustments. Metaphor counseling was used where teachers function as counselors and facilitators. Thus, in the teachings there were lots of drills and individual exercises adjusted in stages.

The implementation of the method, the teachers created an atmosphere that allows students (in class) to interact and communicate with other fellow students freely. Thus, the students experience overall input through their mind (cognition capability) and feeling (affection capability).

Ideally, this method covers some steps namely reflection, recording, discussion, transcription, and analysis. However, based on the observation, only two steps were used during the teaching process namely, reflection and recording. In reflection step, the participants fully depend on the teacher. The participants formed a small circle near the recorder in order to create the community atmosphere. The teachers stood around them while continue facilitating the participants. Participants started thinking and considering about the topic of the conversation, then the teachers gave small instructions. Then, participants started with greetings; morning greeting, afternoon greeting, and night greeting. To ensure that the topic was agreed for discussion, the teachers wrote in papers and trained the participants to spell the sentences. In recording step, participants told what they want to say in first language, the teachers gave the translation in target language (English). When the participants tried saying what they want to say in target language, the teachers ask them to say the words repeatedly. When teachers felt that the participants had comfortable with what they said, the teacher tried to give words/phrase which were more complex. One by one, the participants started pronouncing the greetings in English, then the teachers recorded their pronunced greetings. These two steps were performed in the teaching process. The researchers who were also the teachers spent quite a long time in the repetition part to ensure correct pronunciation from the participants. In the process of teaching, there were many sentences in Indonesian which were asked to be translated into English, particularly in relation to what foreign tourists coming to Asei Island may ask.

\section{Supporting and Barrier Factors In The Implementation of Community Language Learning Method}

This method emphasizes in the language learning process which is not individually, but collectively. In the implementation, supportive environment could create effective learning atmosphere. This is proved when some participants were through discussion after class, that when they gathered and learnt together, they could understand each other's weakness and strengths. Moreover, the participants were not limited only on one topic of conversation. The participants talked freely about everyday life, which thus they could memorize their practices and applied them in their various new conditions.

Based on the results of the observation and teaching, some stages must be skipped because the participants were still in drills or exercises stage and around words which may have bigger portion in their life only. Since this method pays so much attention in humanity aspect to achieve the proficiency of speaking, thus academic aspects were not really concerned. Besides, this method requires a lot of time. Even, recording equipments may become an obstacle when the participants were not familiar with it.

\section{CONCLUSION}

The strong value of the Community Language Learning method is the emphasis that language learning should view students as complete human that receive full support from teacher, absence of judgments, and responsibilities of both parties (teacher and student) as a community. Teachers' role is more of a facilitator and a counselor. The implementation of this method can be vary in different circumstances. However, the method can be used to help a certain community in developing English skill. Through this research, it is expected that Jayapura Regency government 
can pay more attention to people in creative industries, especially painters and sellers of bark painting in helping them developing their ability in English skill, so that they also can feel more confidence in expressing themselves in English.

\section{References}

Bambang, Ag. (2006). Metode penelitian untuk pengajaran bahasa asing: pendekatan kuantitatif dan kualitatif. Yogyakarta: Graha Ilmu

Moleong. LJ. (1999). Metodologi penelitian kualitatif. Bandung: PT. Remaja Rosdakarya Setiyadi.

Nia D. (March 8, 2018). Pembelajaran holistik yang menyenangkan. Retrieved from https://www.sekolahdasar.net/2015/03/pembelajaran- holistik yang menyenangkan.html

Trimawanupy (March 8, 2018). Pembelajaran bahasa indonesia dengan menggunakan pendekatan holistik. Retrieved from https://trimawanupy.wordpress.com/2013/01/12/pembelajaran-bahasa- indonesia-denganmenggunakan-pendekatan-holistik-whole-language/

Wahmad (March 8, 2018). Community language learning.
http://wahmad2810.blogspot.co.id/2013/07/community-language-learning.html

